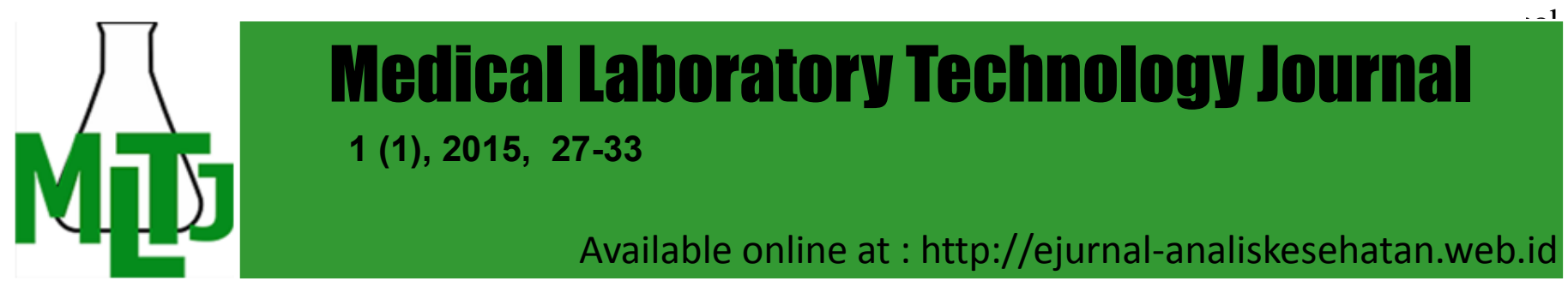

\title{
MRSA DAN VRSA PADA PARAMEDIS RSUD RATU ZALECHA MARTAPURA
}

\author{
Ratih Dewi Dwiyanti, Achmad Muhlisin, Ahmad Muntaha \\ Jurusan Analis Kesehatan Poltekkes Kemenkes Banjarmasin \\ JI Mistar Cokrokusumo 4a Banjarbaru \\ e-mail : Ratihdewi262@yahoo.co.id
}

\begin{abstract}
Abstact: Staphylococcus aureus strains isolated from hospital generally been resistant to many antimicrobial-resistant strains of Staphylococcus aureus to vancomycin was rarely reported. Strains of Methicillin-resistant Staphylococcus aureus (MRSA) is a major cause of nosocomial infections that are multiresistant to antibiotics. This study aims to determine the presence of bacteria Methicillin-resistant Staphylococcus aureus (MRSA) and Vancomycin resistant Staphylococcus aureus (VRSA) on paramedics in the treatment room and the surgical ICU care hospitals Zalecha Martapura queen. This study used a descriptive survey method. The population in this study were nurses who worked in the surgical and ICU care that numbered 38 people. Sampling technique accidental sampling with a sample of 27 people. The survey results revealed 27 positive samples of Staphylococcus aureus 14 people, there is a sensitivity test results of 7 samples were resistant to cefoxitin (MRSA 26\%), 4 samples were resistant to oxacilin and 7 samples were resistant to vancomycin (VRSA 26\%). Concluded there is MRSA and VRSA in hospital Queen zalecha Martapura, it is advisable to increase the cleanliness of individuals and the use of personal protective equipment to reduce the incidence of nosocomial infections in the scope of the hospital.
\end{abstract}

Keywords: MRSA; VRSA; Paramedic

\begin{abstract}
Abstrak: Galur Staphylococcus aureus yang diisolasi dari rumah sakit umumnya telah resisten terhadap berbagai antimikroba, Galur Staphylococcus aureus yang resisten terhadap vankomisin masih jarang dilaporkan. Galur Methicillin-resistant Staphylococcus aureus (MRSA) merupakan penyebab utama infeksi nosokomial yang bersifat multiresisten terhadap antibiotik. Penelitian ini bertujuan untuk mengetahui adanya bakteri Methicillin-resistant Staphylococcus aureus (MRSA) dan Vancomycin resistant Staphylococcus aureus (VRSA) pada paramedis di ruang perawatan bedah dan perawatan ICU RSUD Ratu Zalecha Martapura. Penelitian ini menggunakan metode survey deskriptif. Populasi pada penelitian ini adalah perawat yang bekerja di ruang perawatan bedah dan ruang ICU yang berjumlah 38 orang. Tehnik sampling secara accidental sampling dengan jumlah sampel 27 orang. Hasil penelitian diketahui dari 27 sampel yang positif Staphylococcus aureus 14 orang, hasil uji sensitivitas terdapat 7 sampel resisten terhadap cefoxitin (MRSA 26\%), 4 sampel resisten terhadap oxacilin dan 7 sampel resisten terhadap vancomycin (VRSA 26\%). Disimpulkan terdapat MRSA dan VRSA di Rumah sakit Ratu zalecha Martapura, disarankan untuk meningkatkan kebersihan individu dan penggunaan alat pelindung diri untuk mengurangi kejadian infeksi nosokomial di lingkup rumah sakit.
\end{abstract}

Kata Kunci : MRSA; VRSA ; Paramedis 


\section{PENDAHULUAN}

Methicillin-resistant Staphylococcus aureus (MRSA) mengalami resistensi karena perubahan genetik yang disebabkan oleh paparan terapi antibiotik yang tidak rasional. Transmisi bakteri berpindah dari satu pasien ke pasien lainnya melalui alat medis yang tidak diperhatikan sterilitasnya, dan dapat pula melalui udara maupun fasilitas ruangan, misalnya selimut atau kain tempat tidur (Mahmudah, 2013).

Faktor-faktor terjadinya Methicillinresistant Staphylococcus aureus (MRSA) antara lain lingkungan, populasi, kontak, kebersihan individu, riwayat perawatan, riwayat operasi, riwayat infeksi, diabetes, adanya sebuah luka terbuka dan pengobatan, serta kondisi medis (Arias, 2010 \& Mahmudah, 2013). Petugas pelayanan kesehatan/petugas rumah sakit dapat membawa Methicillinresistant Staphylococcus aureus (MRSA) dalam hidungnya hingga 3 bulan atau lebih (Arias, 2010).

Galur Staphylococcus aureus yang diisolasi dari rumah sakit umumnya telah resisten terhadap berbagai antimikroba, bahkan telah resisten terhadap semua antibiotik yang beredar, kecuali terhadap vankomisin. Galur Staphylococcus aureus yang resisten terhadap vankomisin masih jarang dilaporkan. Galur Methicillin-resistant Staphylococcus aureus (MRSA) merupakan penyebab utama infeksi nosokomial yang bersifat multiresisten terhadap antibiotik, bahkan telah resisten terhadap antiseptik golongan ammonium kuarterner sehingga dapat bertahan di lingkungan rumah sakit (Radji, 2011).

Beberapa dekade terakhir, insiden infeksi Methicillin-resistant Staphylococcus aureus (MRSA) terus meningkat di berbagai belahan dunia. Prevalensi infeksi Methicillinresistant Staphylococcus aureus (MRSA) kini mencapai $70 \%$ di Asia, sementara di Indonesia pada tahun 2006 prevalensinya berada pada angka 23,5\%. Methicillin-resistant Staphylococcus aureus (MRSA) maupun infeksi luka operasi karena bakteri di Indonesia dapat terjadi salah satunya di ruang perawatan bedah (Mahmudah, 2013).

Prevalensi Methicillin-resistant Staphylococcus aureus (MRSA) di Rumah Sakit Atmajaya Jakarta pada tahun 2003 mencapai $47 \%$. Insiden Methicillin-resistant Staphylo- coccus aureus (MRSA) di RSUP Dr. Moh. Hoesin Palembang mencapai 46\%. Berdasarkan penelitian yang dilakukan di ruang Intensive Care Unit (ICU) dan ruang perawatan bedah Rumah Sakit Umum Daerah Abdul Moeloek (RSUDAM) Lampung pada tahun 2013 menunjukkan bahwa terdapat Methicillin -resistant Staphylococcus aureus (MRSA) positif sebanyak 26 sampel (38,24\%) (Mahmudah, 2013). Vancomisin resistant Staphylococcus aureus (VRSA) ditemukan pada 10 dari 64 isolat $(15,6 \%)$ dari membran steteskop di Rumah Sakit Margono Soekarjo, Purwokerto (Anjarwati \& Dharmawan, 2010) Berdasarkan observasi yang dilakukan penulis, Methicillin-resistant Staphylococcus aureus (MRSA) dan Vancomisin resistant Staphylococcus aureus (VRSA) di RSUD Ratu Zalecha Martapura belum pernah dilaporkan.Penelitian ini bertujuan untuk mengetahui adanya bakteri Methicillin-resistant Staphylococcus aureus (MRSA) dan Vancomisin resistant Staphylococcus aureus (VRSA) pada paramedis di ruang perawatan bedah dan perawatan ICU RSUD Ratu Zalecha Martapura.

\section{BAHAN DAN METODE}

Penelitian ini menggunakan metode survey deskriptif, yaitu suatu metode penelitian untuk mengambarkan secara objektif berdasarkan fakta yang ditemukan tentang gambaran Methicillin-Resistant Staphylococcus aureus (MRSA) dan Vancomycin-Resistant Staphylococcus aureus (VRSA) pada Paramedis di Ruang Perawatan Bedah dan Rawat Inap Intensive Care Unit (ICU) RSUD Ratu Zalecha Martapura (Notoatmodjo, 2010).

Sampel penelitian ini adalah paramedis di ruang perawatan bedah dan Rawat Inap Intensive Care Unit (ICU) RSUD Ratu Zalecha Martapura yang berjumlah 27 orang diambil secara accidental sampling. Pengambilan sampel ini dengan mengambil dan memeriksa swab hidung dari paramedik di ruang perawatan bedah dan rawat inap Intensive Care Unit (ICU) RSUD Ratu Zalecha Martapura. 
Pengambilan Sampel : Menjelaskan info penelitian dan tanda tangan surat persetujuan sebagai responden Sampel langsung diambil dari swab hidung menggunakan lidi kapas steril yang sudah dicelupkan kedalam larutan TSB steril. Sampel dimasukkan kedalam tabung reaksi yang sudah disterilkan, tutup dengan kapas.

Pemeriksaan Laboratorium : Isolasi dan Identifikasi Kuman : Sampel swab hidung diinokulasi ke dalam Coklat Agar dan diinkubasi dalam inkubator pada suhu $37^{\circ} \mathrm{C}$ selama 24 jam. Koloni hasil inokulasi dari media Coklat Agar diinokulasi lagi ke dalam Mannitol Salt Agar (MSA) dengan cara mengambil 1 koloni pada media Coklat Agar menggunakan ose steril, dan lakukan penggoresan pada 3 daerah secara zig-zag (agar kuman tidak tumbuh menumpuk). Inkubasi dalam inkubator pada suhu $37^{\circ} \mathrm{C}$ selama 24 jam. Staphylococcus aureus memfermentasi manitol membentuk koloni berwarna kuning dan mengubah warna media menjadi warna kuning.

Pewarnaan Gram dilakukan pada koloni yang tumbuh pada media MSA, yaitu dengan membuat sediaan yang diambil dengan ose steril dan mengeringkan. Memfiksasi, menggenangi dengan Gentian Violet 1\%, mendiamkan selama 3 menit dan mencuci dengan air mengalir. Menetesi dengan Lugol dan mendiamkan selama 1 menit, mencuci dengan air mengalir. Menetesi dengan alcohol 96\% dan mendiamkan selama 30 detik. Mencuci dengan air mengalir dan mengeringkan. Memeriksa di bawah mikroskop pembesaran 1000x dengan menggunakan oli emersi. Gram (-) bakteri berwarna merah, Gram (+) bakteri berwarna ungu. Staphylococcus aureus merupakan gram (+) berwarna ungu.

Lakukan uji biokima dengan menanam koloni yang tumbuh pada media Mannitol Salt Agar (MSA) ke dalam media gula-gula (glukosa, laktosa, manitol, maltosa, dan sakarosa). Hasil pada Staphylococcus aureus yaitu positif (+) pada glukosa dan manitol. Uji koagulase dilakukan dengan cara meneteskan plasma darah (citrat) orang normal pada objek glass dan mengambil beberapa ose koloni kuman yang tumbuh pada media Mannitol Salt Agar (MSA), kemudian dicampur sampai homogen dan dilihat adanya koagulase. Hasil yang menunjukkan Staphylococcus aureus yaitu positif $(+)$ pada uji koagulase.
Uji sensitivitas metode Kirby Bauer. Koloni dari media Mannitol Salt Agar diambil dengan menggunakan ose steril dan dimasukkan ke dalam $\mathrm{NaCl}$ 0,9\% steril, kemudian kekeruhan disamakan dengan standar Mac Farland 0,5 .Suspensi koloni diambil dengan lidi kapas steril, oles merata pada permukaan media agar Muller Hinton, didiamkan selama 10 menit. Tempelkan disk antibiotik Cefoxitin, Oxacillin dan Vancomycin pada 1 plat agar Muller Hinton. Inkubasi pada suhu $37^{\circ} \mathrm{C}$ se-

\begin{tabular}{|l|l|l|l|l|}
\hline $\begin{array}{l}\text { Nama Antibi- } \\
\text { otik }\end{array}$ & $\begin{array}{l}\mathrm{R} \\
(\mathrm{mm})\end{array}$ & $\begin{array}{l}\mathrm{I}(\mathrm{mm}) \\
\text { Cefoxitin }\end{array}$ & $\begin{array}{l}\mathrm{S} \\
(\mathrm{mm})\end{array}$ & $\begin{array}{l}\text { D i s k } \\
\text { Content } \\
(\mu \mathrm{g})\end{array}$ \\
\hline Oxacillin & $\leq 18$ & - & $\geq 29$ & 30 \\
\hline Vancomycin & $<17$ & - & $\geq 24$ & 1 \\
\hline
\end{tabular}

lama 24 jam. Baca diameter hambat kuman.

Pembacaan Hasil Resistensi Antibiotik:

Tabel 1. Resistensi Antibiotik menurut ICMR (2009)

Data diperoleh dari hasil pemeriksaan laboratorium. Hasil dicatat kuman Staphylococcus aureus yang positif. Kemudian hasil uji sensitivitas dari masing-masing antibiotik Cefoxitin, Oxacillin dan vancomycin dinyatakan sensitif atau resisten. Data yang diperoleh dianalisa secara deskriptif dan disajikan dalam bentuk tabel. Persentase (\%) didapat dari proporsi jumlah kuman Staphylococcus aureus positif yang ditemukan dan jumlah resistensi kuman tersebut terhadap antibiotik Cefoxitin, Oxacillin dan vancomycin.

\section{HASIL DAN PEMBAHASAN}

Hasil penelitian diperoleh setelah dilakukan pengambilan sampel terhadap 27 perawat Bedah dan Rawat Inap Intensive Care Unit (ICU) RSUD Ratu Zalecha Martapura pada bulan Agusus 2014, sampel swab hidung kemudian dilakukan identifikasi di laboratorium untuk mengetahui ada tidaknya bakteri Staphylococcus aureus, sampel yang positif terdapat Staphylococcus aureus dilanjutkan uji sensitivitas anibiotik untuk mengetahui ada tidaknya MRSA maupun VRSA ,dari hasil pemeriksaan diperoleh data tertera pada tabel 1

Staphylococcus aureus didapatkan pada 
14 sampel penelitian, setelah 14 sampel tersebut diujikan dengan ketiga antibiotik, terdapat 7 sampel resisten terhadap cefoxitin, 4 sampel resisten terhadap oxacilin dan 7 sampel resisten terhadap vancomycin. Sampel yang resisten terhadap ketiga antibiotik dite- mukan 4 sampel, sedangkan sampel resisten terhadap cefoxitin dan vancomycin sebanyak 6 sampel. Satu sampel hanya resisten terhadap cefoxitin dan juga hanya satu sampel yang resisten terhadap vancomycin saja .

Tabel 2. Hasil Identifikasi dan uji terhadap MRSA dan VRSA

\begin{tabular}{|c|c|c|c|c|c|}
\hline No & Kode Pasien & Hasil identifikasi Bakteri & Cefoxitin $(30 \mu \mathrm{g})$ & Oxacillin $(5 \mu)$ & Vancomycin $(5 \mu \mathrm{g})$ \\
\hline 1 & $\bar{A} 1$ & - & - & - & - \\
\hline 2 & $\mathrm{~A} 2$ & - & - & - & - \\
\hline 3 & $\mathrm{~A} 3$ & Staphylococcus aureus & $\bar{R}$ & $\bar{R}$ & $\bar{R}$ \\
\hline 4 & A4 & - & - & - & - \\
\hline 5 & A5 & - & - & - & - \\
\hline 6 & A6 & - & - & - & - \\
\hline 7 & A7 & Staphyloccccus aureus & $S$ & $\mathrm{~S}$ & $S$ \\
\hline 8 & A8 & Staphylococcus aureus & $\bar{R}$ & $\bar{R}$ & $\bar{R}$ \\
\hline 9 & A9 & -- & - & - & - \\
\hline 10 & $\mathrm{~A} 10$ & Staphylococcus aureus & $\bar{R}$ & $\bar{R}$ & $\bar{R}$ \\
\hline 11 & B1 & Staphylococcus aureus & $\mathrm{R}$ & $\mathrm{R}$ & 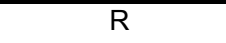 \\
\hline 12 & B2 & - & - & - & - \\
\hline 13 & B3 & - & - & - & - \\
\hline 14 & B4 & - & - & - & - \\
\hline 15 & B5 & Staphylococcus aureus & $\overline{\mathrm{R}}$ & $\mathrm{S}$ & $\bar{R}$ \\
\hline 16 & $\mathrm{~B} 6$ & Staphylococcus aureus & $\mathrm{S}$ & $\bar{S}$ & $\bar{S}$ \\
\hline 17 & B7 & Staphylococcus aureus & $S$ & $\mathrm{~S}$ & $S$ \\
\hline 18 & B8 & - & - & - & - \\
\hline 19 & B9 & $\overline{-}$ & - & - & - \\
\hline 20 & B10 & Staphylococcus aureus & $\mathrm{R}$ & $S$ & $\mathrm{~S}$ \\
\hline 21 & B11 & Staphylococcus aureus & $\mathrm{S}$ & $\mathrm{S}$ & $\mathrm{S}$ \\
\hline 22 & B12 & Staphylococcus aureus & $S$ & $S$ & $S$ \\
\hline 23 & B13 & Staphylococcus aureus & $\mathrm{S}$ & $\mathrm{S}$ & $\mathrm{R}$ \\
\hline 24 & B14 & Staphylococcus aureus & $S$ & $S$ & $\mathrm{~S}$ \\
\hline 25 & B15 & - & - & - & - \\
\hline 26 & B16 & Staphylococcus aureus & $\bar{R}$ & $\mathrm{~S}$ & $\bar{R}$ \\
\hline 27 & B17 & - & - & - & - \\
\hline
\end{tabular}

Keterangan = Tanda (-): ada pertumbuhan bakteri tetapi bukan Staphylococcus aureus, S: Sensitif, I: Intermediet, R: Resisten

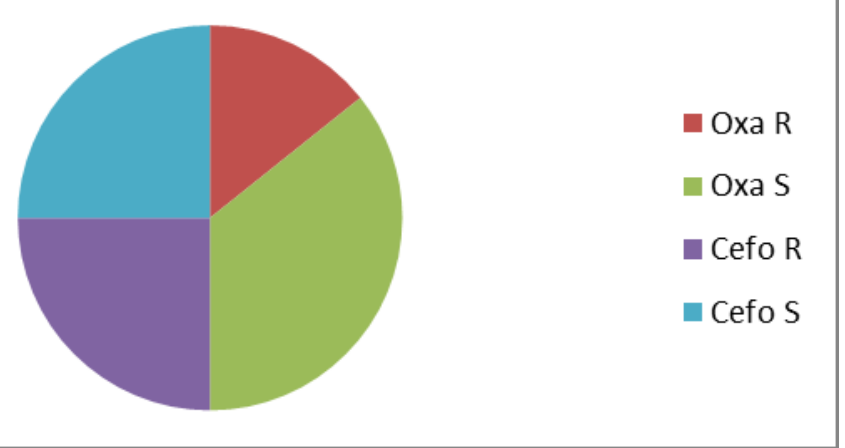


Medical Laboratory Technology Journal

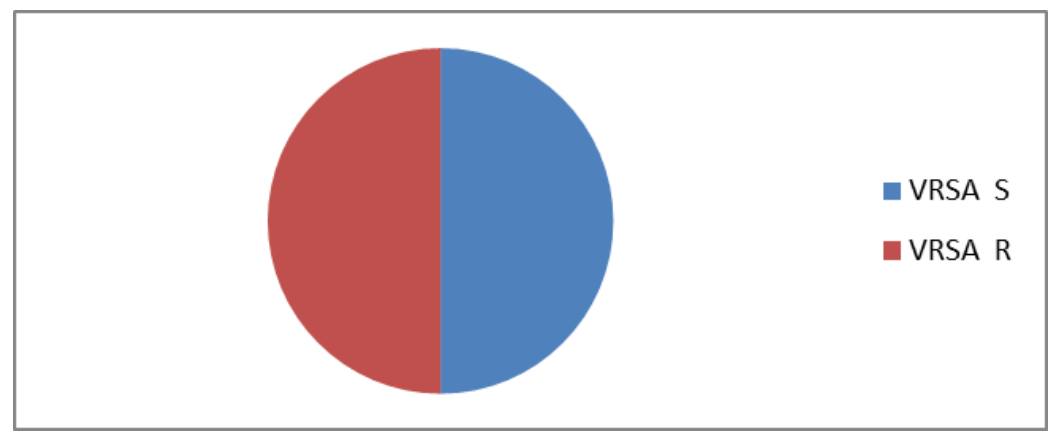

Grafik 2. Hasil pemeriksan VRSA (antibiotik vancomycin)

Hasil penelitian dari 27 sampel swab hidung para perawat yang bekerja diruang bedah dan ICU semua menunjukkan adanya pertumbuhan bakteri tetapi hanya 14 sampel terdapat Staphylococcus aureus. Sampel yang positif pertumbuhan Staphylococcus aureus dilanjutkan uji sensitivitas terhadap antibiotik golongan methicillin yaitu cefoxitin $(30 \mu)$ dan oxacillin $(5 \mu \mathrm{g})$ serta antibiotik vancomycin (5 $\mu g)$.

Ditemukannya bakteri Staphylococcus aureus pada 14 sampel merupakan hal yang wajar mengingat Staphylococcus aureus merupakan salah satu flora normal pada saluran pernafasan bagian atas (saluran hidung) sekitar $20-30 \%$ (Brook,dkk,2008).

Staphylococcus aureus telah berevolusi terhadap antibiotik yang biasa dipakai untuk membunuh kuman ini dalam perjalanan pemakaian antibiotik. Terakhir golongan kuman ini telah resisten terhadap methicillin sehingga dikenal dengan nama Methicillin-Resistant Staphylococcus aureus (MRSA) dan pertama kali dilaporkan pada tahun 1960 (Wirahjasa dan Putu, 2012).

Hasil uji pada table 1. diketahui dari 14 sampel yang diuji terdapat 7 sampel resisten terhadap cefoxitin, 4 sampel resisten terhadap oxacilin dan 7 sampel resisten terhadap vancomycin. Sampel yang resisten terhadap ketiga antibiotik ditemukan 4 sampel, sedangkan sampel resisten terhadap cefoxitin dan vancomycin sebanyak 6 sampel. Satu sampel hanya resisten terhadap cefoxitin dan juga hanya satu sampel yang resisten terhadap vancomycin saja.

MRSA dapat ditentukan dengan melihat hasil resisten terhadap antibiotik cefoxitin dan oxacilin. Penelitian ini menemukan 7 sampel yang resisten cefoxitin dan hanya 4 sampel resisten oxacilin. MRSA pada penelitian ini ditentukan dengan penggunaan cefoxitin karena lebih akurat dibandingkan oxacillin. CLSI (Clinical Laboartory Standard Interna- sional) merekomendasikan penggunaan cefocitin dengan metode difusi cawan /Kirby bauer untuk menentukan MRSA (Yuwono,2012).

Sampel penelitian yang resisten terhadap vancomycin terdapat 7 , sehingga VRSA dikatakan positif pada 7 sampel. Resisten terhadap cefoxitin dan juga vancomycin ditemukan pada 6 sampel, sehingga sampel yang MRSA dan juga VRSA adalah 6 sampel.

Hasil penelitian diatas menunjukkan bahwa Staphylococcus aureus tidak hanya resisten terhadap antibiotik jenis methicillin tetapi juga sudah ada yang resisten terhadap antibiotik golongan glikopeptida salah satunya adalah vancomicin.

Ketika ditemukan Staphylococcus aureus resisten methicillin maka antibiotik pilihannya adalah golongan glikopeptida salah satunya vancomycin tetapi akibat penggunaan vancomycin yang terus menerus Staphylococcus aureus menjadi resisten terhadap vancomycin, hal ini telah dilaporkan Hong Bin Kin dkk (2003) menyatakan Staphylococcus aureus merupakan salah satu patogen yang paling penting menyebabkan morbiditas berat dan infeksi fatal.

Sejak isolasi pertama methicillin-resistant Staphylococcus aureus (MRSA) di Inggris pada tahun 1961, prevalensi MRSA meningkat pesat di seluruh dunia, sehingga antibiotik glycopeptide telah banyak diandalkan untuk mengobati infeksi MRSA . Pada tahun 1996, di Jepang diketahui adanya infeksi Staphylococcus aureus yang mengalami penurunan kerentanan terhadap vancomycin (vancomycinintermediate Staphylococcus aureus (VISA). Setelah itu, sekitar 20 kasus, infeksi VISA telah dilaporkan di beberapa negara, termasuk Korea. Selanjutnya, 2 isolat VRSA ditemukankan di Amerika Serikat tahun 2002. 
Pernyataan diatas menunjukkan bahwa selain MRSA, beberapa tahun terakhir ini VRSA sudah mulai banyak ditemukan di banyak Negara termasuk di Indonesia. Staphylococcus aureus telah lama dikenal sebagai patogen utama rumah sakit pada infeksi yang didapat di rumah sakit. Selama dekade terakhir, methicillin-resistant Staphylococcus aureus (MRSA) strain telah menjadi endemik di rumah sakit di seluruh dunia. Selain itu, sekarang patogen komunitas baru menjadi banyak di wilayah geografis MRSA ini penting karena, selain menjadi resisten methicillin, sebagian besar strain juga tahan terhadap antibiotik $\beta$ - laktam lainnya, dengan pengecualian antibiotik glycopeptide.

Pada 1980-an, karena luasnya kejadian MRSA, terapi empirik untuk infeksi Staphylococcus (sepsis terutama nosokomial) diubah menjadi vancomycin di banyak institusi perawatan kesehatan. Vancomycin digunakan di Amerika Serikat juga meningkat selama periode ini karena meningkatnya jumlah infeksi dengan Clostridium difficile dan koagulase negatif staphylococci ( kontra ) di lembagalembaga perawatan kesehatan. Dengan demikian awal 1990-an telah menunjukkan peningkatan yang dilihat dalam penggunaan vancomycin. Akibatnya, tekanan selektif yang akhirnya menyebabkan munculnya strain Staphylococcus aureus dan spesies lainnya dari staphylococci dengan penurunan kerentanan terhadap vancomycin dan glikopeptida lain .

Pada tahun 1997, strain pertama dari Staphylococcus aureus dengan kerentanan yang menurun terhadap vancomycin dan teicoplanin dilaporkan dari Jepang. Tak lama setelah itu, dua kasus tambahan dilaporkan dari Amerika Serikat. Isolat klinis pertama vancomycin-resistant Staphylococcus aureus (VRSA) dilaporkan dari Amerika Serikat pada tahun 2002 (Tiwari and Sen, 2006).

Di Indonesia Penelitian Vancomycin resistant Staphylococcus aureus (VRSA) ditemukan pada 10 dari 64 isolat $(15,6 \%)$ dari membran steteskop di Rumah Sakit Margono Soekarjo, Purwokerto (Anjarwati \& Dharmawan, 2010). Dari uraian diatas diketahui bahwa saat ini tidak hanya MRSA saja yang dikhawatirkan tetapi juga VRSA,

Resistensi terhadap antibiotik dapat disebabkan oleh gen tertentu pada bakteri yang mengalami mutasi kromosomal sehingga bakteri kebal terhadap antibiotic tertentu, bak- teri mendapatkan gen resisitensi ekstrakromosomal melalui proses transformasi, transduksi, transposon ataupun melalui pemindahan fragmen DNA lainnya (Radji, 2011). MRSA terbentuk oleh karena terdapatnya mecA gene, pengkode resisten terhadap metisilin yang ditemukan pada $S$. aureus. Gen resisten ini mengkode Penisilin Binding Protein 2a (PBP 2a) yang tidak mengikat metisilin sebagaimana pada mestinya.

Pada MRSA di komunitas, kerap kali dijumpai adanya infeksi yang berat dan progresif. Hal ini rupanya disebabkan adanya toksin Panton-Valentine leukocidin (PVL), (Vanko et.al ; Muttaiyah et.al dalam Ronald, 2013) yang kemudian dapat menyebabkan timbulnya abses, destruksi leukosit dan bahkan necrotizing pneumonitis.(Muttaiyah et. al. ,dalam Ronald, 2013). Namun hingga saat ini belum dapat dijelaskan sepenuhnya mengenai mekanisme bagaimana terjadinya perubahan genetik dan biokimiawi pada Stafilokokus aureus hingga menjadi resisten terhadap vancomycin (Vanko et.al, dalam Ronald ,2013)

Adanya petugas kesehatan yang terinfeksi atau terkolonisasi MRSA maupun VRSA dapat berperan sebagai reservoir. Petugas kesehatan yang terkolonisasi MRSA maupun VRSA dalam jangka panjang dapat menjadi sumber penular dalam sebuah unit perawatan intensif bedah ,carrier (pembawa) yang membawa organisme dihidung. Sebagian besar orang menjadi carrier MRSA bersifat asimptomatik dan tidak pernah memperlihatkan gejala klinis,terutama apabila mereka sehat (Gould \& Christine, 2003).

Dari hasil penelitian 6 sampel $(42,9 \%)$ menunjukkan sifat sensitif terhadap methicillin maupun vancomicin, hal ini menunjukkan bahwa adanya Staphylococcus aureus dilingkup rumah sakit Ratu Zalecha Martapura tidak semua mengalami resistensi, meskipun demikian penggunaan antibiotik methicillin maupun vancomycin harus dibatasi agar tidak meningkatkan persentase MRSA maupun VRSA di masa mendatang.

Peningkatan persentase MRSA maupun VRSA di lingkup rumah sakit dapat berakibat negatif pada siapapun yang berada di rumah sakit karena adanya infeksi nosokomial sehingga dapat menyulitkan pada proses pengobatan, untuk mencegah terjadinya penularan perlu dilakukan kesadaran terhadap kebersihan individu dan penggunaan alat pelindung 
diri karena kedua hal ini termasuk dalam tindakan pengendalian MRSA maupun VRSA di rumah sakit yang meliputi mencuci tangan, surveilans laboratorium, surveilans untuk mendeteksi pasien yang terinfeksi dan terkolonisasi, pencegahan kontak dan penggunaan alat pelindung diri (seperti sarung tangan,masker dan apron), pendidikan bagi petugas pelayanan kesehatan berkaitan dengan pencegahan penyebaran mikroorganisme, pengobatan bagipasien dan petugas yang terinfeksi, dekolonisasi petugas dan pasien di dalam situasi tertentu (Arias, 2010).

Hasil pemeriksaan Methicillin-Resistant Staphylococcus aureus (MRSA) di di dunia kedokteran menjadi masalah besar selama bertahun-tahun karena berperan sebagai penyebab infeksi nosokomial yang bersifat resisten terhadap antibiotik, salah satunya Cefoxitin dan Oxacillin dengan angka kejadian 10-20 \% (Nurkusuma, 2009)

\section{KESIMPULAN}

Staphylococcus aureus terdapat pada 14 sampel swab hidung paramedis di ruang perawatan bedah dan ICU RSUD Ratu Zalecha Martapura. Hasil uji sensitivitas terdapat 7 sampel resisten terhadap cefoxitin, 4 sampel resisten terhadap oxacilin dan 7 sampel resisten terhadap vancomycin. MRSA ditemukan 7 (26\%) sampel (ditentukan dengan resistensi cefoxitin), VRSA ditemukan 7 $(26 \%)$ sampel dan dari masing-masing sampel tersebut sebanyak $6(22 \%)$ sampel gabungan MRSA dan VRSA.

\section{DAFTAR PUSTAKA}

Anjarwati D.U dan Dharmawan A.B. (2010), Identifikasi Vancomisin resistant Staphylococcus aureus pada membran stetekop di Rumah Sakit Margono Soekarjo Purwokerto, Mandala of Health, Vol 4, No.2

Arias, KM (2010), Investigasi dan Pengendalian di Fasilitas Pelayanan Kesehatan, EGC, Jakarta

Brooks, GF, Butel \& Morse, SA , (2008), Jawez, Melnick, Adelberg Mikrobiologi Kedokteran, Edisi 23, EGC, Jakarta

Gould,Dinah \& Christine Brooker, (2003), Mikrobiologi terapan untuk perawat, EGC, Jakarta

Hong Bin Kin et.al, (2003), Nationwide Sur- veillance for Staphylococcus aureus with Reduced Susceptibility to Vancomycin in Korea, J. Clin. Microbiol. June 2003 vol. 41 no. 6 2279-2281

Indian Council of Medical Research (ICMR), (2009), Detection of Antimicrobial Resisten in Common Gram negatif and Gram Positif Bacteria Encountered in Infectious Dieases-an Update, ICMR Offset Press, New Delhi

Mahmudah, R, Soleha, TU \& Ekowati, C (2013), 'Identifikasi Methicillin-Resistant Stapylococcus aureus (MRSA) pada Tenaga Medis dan Paramedis di Ruang Intensivecare Unit (ICU) dan Ruang Perawatan Bedah Rumah Sakit Umum Daerah Abdul Moeloek', Medical Journal of Lampung University, vol 2, pp. 71-76.

Notoatmodjo, S (2010). Metodologi Penelitian Kesehatan, Rieke Cipta, Jakarta

Nurkusuma, DD, (2009), 'Faktor yang Berpengaruh terhadap Kejadian MethicillinResistant Staphylococcus aureus (MRSA) Pada Kasus Infeksi Luka Pasca Operasi Di Ruang Perawatan Bedah Rumah Sakit Dokter Kariadi Semarang', Tesis Universitas Diponegoro, Semarang.

Radji, Maksum (2009), Buku Ajar Mikrobiologi Panduan Mahasiswa Farmasi dan kedokteran, EGC, Jakarta.

Ronald I, (2013), Pola Kepekaan dan Resistensi mikroorganisme aerob penggunaan antibiotika dan manfaat kultur pada infeksi kulit dan jaringan lunak komplikata di ruang rawat inap penyakit dalam Rumah sakit Cipto mangunkusumo, Tesis, FKUI, Jakarta

Tiwari \& Sen, (2006), Emergence of vancomycin resistant Staphylococcus aureus (VRSA) from a tertiary care hospital from northern part of India, BMC Infectious Diseases 2006, 6:156 doi:10.1186/1471 -2334-6-156

Wirahjasa \& Panji, (2012), Pengelolaan infeksi akibat Mehicillin- Resistant Saphylococcus aureus, Majalah kedokteran Terapi Intensif , Volume 2,juli 2012,p.135

Yuwono, (2012), Staphylococcus aureus dan Methicillin reisitant Saphylococcus aureus (MRSA), Departemen Mikrobiologi FK Unsri, Sumatra Selatan 